\title{
Search for Ancestral Roots in Morgan Jerkins's Wandering in Strange Lands
}

\author{
Rashad Mohammed Moqbel Al Areqi ${ }^{1}$ \\ ${ }^{1} \mathrm{Al}$ Baha University, Fcaulty of Sciences and Arts, Al Mandaq, KSA \\ Correspondence: Rashad Mohammed Moqbel Al Areqi, Al Baha University, Fcaulty of Sciences and Arts, Al \\ Mandaq, KSA.
}

Received: December 20, 2021

Accepted: January 20, $2022 \quad$ Online Published: January 28, 2022

doi:10.5430/wjel.v12n1p154

URL: https://doi.org/10.5430/wjel.v12n1p154

\begin{abstract}
Many African Americans seek to unravel their history and ancestral roots, much of which was lost during the Great Migration that took place between 1916 and 1970. Morgan Jerkins's Wandering in Strange Lands (2020) explores the history and the ancestral roots of the Jerkins family, along both the paternal and maternal lineages. Written as a memoir, rather than a historical or genealogical report, the narrative is supported by documents, records, transcripts, photos and interviews conducted by Jerkins herself. Her research uncovers the stories of other African-Americans and their native identity that sheds more light on Jerkins's own roots, as well as the traditions of Blacks in general. Using a postcolonial lens, themes of migration, dislocation, ethnicity, marginality, Creole identity and diaspora are examined not only from the historical and genealogical viewpoint of the Jerkins family, but also from the perspective of the major groups of the Great Migration, who left the American South for other cities. Eventually, Jerkins's arduous journey uncovers her family's hidden past, a heritage that has been influenced by the Great Migration and the displacement of African-Americans leaving hard life conditions in search of better job opportunities in the Northeast, the Midwest, and the West Coast, in particular. The Great Migration was an attempt by Blacks to release themselves from the shackles of the oppression of White supremacy. Jerkins manages to find her heritage-language, rituals, beliefs, symbols and traditions intertwined with superstitions - and she is able to connect with her tribal roots and legacy.
\end{abstract}

Keywords: wandering, ancestrality, roots, migration, African Americans, diaspora, displacement

\section{Introduction}

In the narrative of Wandering in Strange Lands, Morgan Jerkins traces her family's roots to become more familiar with her genealogical history, much of which was lost as a result of the Great Migration. This movement pushed Black Americans to leave their homes in the South for better economic opportunities in the North, West, and Midwest, disconnecting the Black Americans from their roots, homes and family history. Over the course of Jerkins's search for her family ancestry, she also uncovers the history of Blacks who have been displaced and oppressed by Whites throughout American history.

Jerkins's Wandering in Strange Lands provides deep insight into Black history in general, traced back over 300 years as stated in the narrative. Through Jerkins's personal research and exploration of Black Americans who moved to different places, she was able to collect excellent data about their history through interviews, public records, transcriptions, letters and photos, as well as about her own family.

The narrative enthralls readers with the legacy of the Jerkins family, which becomes the path to understanding more about Black Americans in general. The book investigates the struggle of African Americans for survival and how they left their homes and what was familiar, forgetting their sense of identity and belonging through their efforts to seek a better life: "No one spoke about the past-the goal was to move forward and never look back" (p.8). The significance of this journey for Jerkins is the meticulous unveiling of information about the past and Black traditions, which have long been neglected and marginalized. Jerkins attempts to reconnect with the cultural and spiritual legacy of Black Americans, a quest that in many ways remains unfulfilled and cannot leave her memory. Other African American writers have also attempted to uncover their family history and legacy by writing about the displacement of Blacks across America. It is a painful journey into the past, but one that is not without rewards. 
Jerkins clarifies her task in this journey: "to excavate the connective tissue that complicates but unites us as a people, and to piece together the story of how I came to be by going back and looking beyond myself" (p.11). She seeks her ancestral identity, to find answers to her questions about the traditions and beliefs of her ancestors that she has wondered about throughout her life. Jerkins begins her search in Georgia, and then moves on to South Carolina, Louisiana, Oklahoma and California, each state leading her to new knowledge about the traditions and identity of her Black ancestors. The following section will provide a brief overview of the Great Migration and its impact on Black Americans.

\section{African Americans and the Great Migration}

Jerkins is a Black American writer who focuses on race and Black American history. She was raised by her mother in New Jersey, and her father is from North Carolina. For Wandering in Strange Lands, Jerkins travelled to different states where her ancestors, and many other Black families, lived before the Great Migration to trace the lineage of Black Americans to their original African ethnic groups. Her goal was to answer her genealogical and historical questions about her ancestry, as well as to gain a better understanding the history of the Black Americans and highlight its socio-historical value.

The narrative writings of African Americans lend cultural, social and political texture to oppressed peoples, and not just in the United States. These writings are a source of inspiration for people around the world who are suffering from racial and ethnic discrimination. Postcolonial studies have given Black writing, especially novels, a large platform, with most concepts in the genre addressing the particular experiences of Blacks and oppressed peoples. This study will address some of the postcolonial concepts that emerge in Jerkins's Wandering in Strange Lands.

Among these is the concept of the African American diaspora. The term diaspora has been used by the Greeks to indicate a sense of being "dispersed." Bill Ashcroft et al. (2007) elucidated the term as "the voluntary or forcible movement of peoples from their homelands to new regions" (p.68). In the United States, this phenomenon was a historical fact, with White supremacy at the center and African Americans on the periphery. Accordingly, diasporic communities emerged as a result of the dislocation of large numbers of African Americans. The term dislocation can have multiple meanings. One is connected to the involuntary or coerced transport of people from one country to another, or from one region to another inside the same country. This type of movement can sometimes be voluntary, such as to find better economic conditions, but it became obligatory in order to respond to demands of segregation that forced Blacks to leave their homes and lands.

On the other hand, dislocation can also take on another meaning, one in which native/ancestral cutures, language and traditions are purposefully distorted or annihilated. Subjugated to slavery and segregation, African Americans were forced to ignore their history and culture to allow White culture and language to prevail. This kind of dislocation has kept African Americans on the margins. Therefore, the term ethnicity is manifested from the transformations of human culture, language, traditions and even ancestry: "ethnicity refers to the fusion of many traits that belong to the nature of any ethnic group: a composite of shared values, beliefs, norms, tastes, behaviors, experiences, and consciousness of kind, memories and loyalties" (Ashcroft, 2007, p.80).

For example, Creole is connected to African Americans and is mentioned in Jerkins's personal exploration. Originally taken from the Portuguese word "crioulo," meaning "native," the French derivative of creole means "indigenous." Eventually, the word was used to refer to settlers or im/migrants to America or Europe. Later, Creole was used to indicate the language spoken by people who came to the United States from West Africa as slaves.

Karida Brown's Gone Home details the mass migration of Blacks who moved into and out of the coalfields of Appalachia between 1910 and 1970. The coalfields were a layover from the rural South to the North, Midwest, and West. Gone Home illustrates the significance of this stop in terms of collective identity and intergenerational migration. It portrays the lives of Blacks in the coal mining towns of Appalachia, which has been depicted as a White region, essentially ignoring the existence of Blacks. Gone Home attempts to bridge this gap, revealing how the coalfields of eastern Kentucky were home for two generations of African American migrants. Simultaneously, the book revives communal memory, in spite of the segregation and discrimination of the Jim Crow era (Mah, 2019).

In the early twentieth century, the first wave of the Great Migration saw a limited number of African Americans settling in California, with Blacks not exceeding $2 \%$ of the state population. During the second wave, roughly from 1940, this number increased rapidly and covered many cities in California, including Berkeley, Emeryville, Vallejo and Richmond. In Compton, the Black population grew from zero to $40 \%$ by 1960 (Reny \& Newman, 2018).

The Great Migration was a hallmark in the history of American labor market development. The term Great Migration is used only to refer to Black migration out of the South, undoubtedly fueled by the experience of racial oppression 
and segregation. Whereas Black migrants initially moved to the North and Midwest, southern Whites frequently moved West in search of better economic conditions. Racial discrimination in the South did not provide Blacks with any opportunity to advance, either in educationally or financially (Collins and Wanamaker, 2015).

Racial violence between Blacks and Whites erupted for a number of reasons, including false accusations of Black men raping White women, often resulting in the death of the accused. Tibbs (2021) explained that "the racist history of the South is drenched in the blood of the Black men lynched because of White women" (p.204). Whites sought a scapegoat in order to inflict harm on Blacks, and that scapegoat became White women. The development of a culture of fear based on the premise of White female purity and the superiority of the White race meant that race mixing would not stand. To reinforce this perception of a pure race and supremacy, Whites refused to share social space with Blacks and proceeded to narrow the circle of Black movements, ostensibly to protect White lineage. African - American history has borne witness to many examples of lynching, supported by the laws and the silence of the government:

Ida. B. Wells tells a story of a wife of a minster in Ohio who accused a Black man of raping her, claiming that he forced entry into her home. Despite his denials, and without piece of factual evidence, her trial testimony was validated over his, and he was convicted. (Tibbs, 2021, p. 207)

There are countless examples of human rights violations and oppression of Blacks, with false allegations of assault or other crimes resulting in the conviction and even death of Blacks. Whites called the police for any skeptical behavior or expected violation, resulting in Black arrests based on false accusations. Many of the reported allegations against Blacks were for no genuine reason aside from the intention to harm Blacks (Tibbs, 2021). Law enforcement officers also engaged in regular and brutal attacks against both Black women and men in many areas of the South, and not even White religious men took any serious steps to stop their followers from violating Blacks. This revealed more allegiance to their race than their religion.

The first generation of the Great Migration tended to achieve poorer economic returns, but they paved the way for the second generation to be better off financially. Alexander et al. (2017) revealed the significance of the Great Migration for future generations:

...that migration to the North and West yielded advantages for migrants' children, advantages that are apparent far into their adulthood and are particularly evident among black migrants. Specifically, black second-generation migrants exhibit higher incomes and probabilities of graduating from high school and lower probabilities of being in poverty than their southern stayer counterparts. (p.17)

The second wave of the Great Migration forced American policies to respond to the reality of millions of Blacks moving out of the South and demanding equal rights. During the second wave of the Great Migration, between 1940 and 1970, more than 4 million African Americans moved to the North. In that period, the civil rights movement eventually ended institutionalized racial discrimination, creating a turning point in White-Black relations. The Great Migration empowered Black Americans on three different levels: political, economic, and educational.

A vocal and growing social movement forced policymakers, especially in the North, to respond to these political demands, starting with granting Black migrants civil rights, including the opportunity to vote. The Great Migration also paved the way for a new era of race relations, eventually putting an end to political disenfranchisement. With the creation of better economic opportunities and civil rights came the urgent demand for Blacks to participate in the political process (Calderon et al., 2021). On the other hand, the Great Migration left a negative influence on African Americans in the long run because it prompted Whites to move to leave urban areas for the suburbs, increasing racial segregation.

For many Blacks, moving away from the South was the only solution for survival. The South did not provide opportunities for the first or subsequent generations, instead reinforcing a heavily segregated social and economic hierarchy through the violence of the Ku Klux Klan, voter disfranchisement and the financial drain of tenant farming. However, Gardner (2016) argued that the impact of the Great Migration "caused large declines in wages for Blacks, with little effect for Whites" (p.1). Blacks resided in a small number of metropolitan areas where the labor markets were segregated, resulting in limited opportunities for Blacks and a great deal of competition for work. The exodus North reshaped Black and White communities alike, shifting the demographics of the North in ways that are still felt today: "It changed the whole profile and landscape of American cities: culturally, politically, and socially," says James R. Grossman, author of Land of Hope: Chicago, Black Southerners, and the Great Migration. "There was absolutely nothing about urban lifethat wasn't reshaped by the Great Migration” (Klder, 2016, p, 17).

\section{Jerkins's Search for Her Missing Half}

Wandering in Strange Lands is divided into several chapters, with some assigned to a particular region: Prologue; The Milkman Baby; Part I: Lowcountry, Georgia and South Carolina; Part II: Louisiana Creole; Part III: Oklahoma; Published by Sciedu Press 
Part IV: Los Angeles; and the Epilogue. The research of this paper addresses the regionally-focused chapters, as well as Jerkins's discoveries that lead her to her roots and the traditions of the Black community in general. In the epilogue, Jerkins actually introduces herself and her family, and explains that as a light-skinned Black, she looks different from her sisters and other members of the family. Her father claims: "That's the milkman's baby" (p. 6). Her light color distinguishes Jerkins not only within her own family, but also in her neighborhood and church.

Wishing to find her roots, Jerkins knows she cannot move forward without knowing her family's past, especially her maternal and paternal genetic history: "my original certificate indicates that my story is half missing...there was a blank spot where my father's name should've been" (p.6). Therefore, Jerkins begins her journey by becoming familiar with her family's lineage. Her mother is a first generation migrant who does not pay too much attention to the details of the past. Her father, on the other hand, is second generation with a significant connection to the past: "he knows there is nothing like that soil 'down there," (p.7). Although Jerkins's father yearns for the past and lost land, the hard conditions of life in the South did not give him an opportunity to reflect on his identity or roots.

Jerkins's family does not want to be bothered with searching the past. Reviving a traumatic past also bring its pains and therefore, there is a tendency to leave the past behind. Jerkins is not like the rest of her family, or the generations who ignore or aren't very interested in the past: "No one spoke about the past - the goal was to move forward and never look back" (p. 8). Jerkins seeks the details of her past, such the history behind the family's middle name, for which there is no ample information. These gaps in her family knowledge serve as an impetus for her search for her roots: "I was weary with my conception of self, of the diaspora, as one of loss" (p.10).

The journey Jerkins plans follows the migratory routes of the past, and she compares what she sees to what she has heard. She provides deep insights into the differences and similarities between the African Americans in the target destinations. Her travels illuminate Black culture, religion, language, traditions and symbols, which are sometimes intertwined with superstitious habits. Eventually, Jerkins can recreate her identity, "to excavate the connective tissue that complicates but unites us as a people, and to piece together the story of how I came to be by going back and looking beyond myself - a liberating and healing pilgrimage" (p.11). It is a hard journey that enables her to probe deeply into her ancestors' history.

\section{The Traditions and Superstitions of the Gullah Geechee}

Jerkins's first destination is Georgia where she begins to unravel the puzzles of water, soul food, magic, rootwork, hoodoo and the roots of relationships between African Americans in Georgia and other states. As a child, Jerkins was taught to be afraid of water, and she seeks to know the reasons behind these fears. She also wants to uncover the secret behind her light color, so different from that of her family. But the work begins with soul food, both its origin and name. Soul food travelled with African Americans North during the Great Migration, becoming known as the food that brings together all members of the family for special occasions, such as Christmas Day.

The roots of soul food reach back to the interior of the South, with traditional dishes becoming part of Black cuisine in the North, where "they tried to re-create home" (p.14). Jerkins highlights the word "soul" and its origin as "emotional fervor in the 1940s. Soul dishes include macaroni and cheese, chitlins, collard green, yams, sweet potatoes pie and peach cobbler. Hoppin' John (black-eyed peas and rice) is intricately involved with superstitions found in the Lowcountry of Georgia and South Carolina practiced by the Gullah Geechee, who originally came from West and Central Africa: The Gullah Geechee people are the oldest sub-ethnic group of African Americans" (p. 18). The name Geechee might have been taken from the Ogeechee River, which flows through Georgia, or the Kissi people of Guinea, Sierra Leone and Liberia, according to Jerkins's investigation. In Gullah Geechee culture and traditions, Hoppin' John is eaten for good luck, along with collard greens for prosperity.

Some Traditions have been maintained by the Gullah Geechee in spite of White oppression against Blacks. Segregation is a hallmark of Black history, effectuated in public spaces to appease Whites, such as designating Chicken Bone Beach exclusively for Blacks. Jerkins attempts to uncover the reasons associated with the fear of water and other superstitions attached to African Americans by starting with the culture of the Gullah Geechee.

First generation migrants, like Jerkins's mother, always warned their children, especially the females, to avoid playing in any body of water:

"Don't put your head underneath the water, or else the chlorine will mess up all that pretty hair." "Don't go off into the deep end." "Be where I can see you." "Don't horseplay too much." "Don't swim when there's no adult around." Or simply, "Don't you get in that pool." (p. 26)

Moreover, African Americans did not teach their children to swim because "they didn't want to lose us" (p. 26). This fear of water is intertwined with Black culture and traditions. The Gullah Geechee community is intimately Published by Sciedu Press 
connected to their access to water. Land and water mark both the spiritual and physical lives of the Gullah Geechee: "water is the bloodline for Gullah people is because it is one of their main sources of food" (p.28). The natural landscape influenced African Americans and became part of their culture and customs. Most of the Lowcountry is covered with water, which may have aroused fear in the hearts of Blacks: "The ocean, lakes, marshes, and rivers encircle the lives of Gullah people. Not only does the water provide the food they need to stay alive, but it is a portal between the living and the dead" (p.28).

Many African Americans lost their children in water, such as the Mississippi River or the Atlantic Ocean, which would have implanted a deep fear of loss. Therefore, water became a symbol of death rather than life: "Water held memories of ancestors' deaths," (p. 34). Water is the bloodline of not only the Geechee people, but for African Americans in general, and their fear of water was transported with them to the North. This fear was so deeply rooted that it was passed on from the first generation to the second, because the lives of so many African Americans were ended by water.

The second puzzle Jerkins seeks to solve is magic and its association with superstitions. She tries to uncover the secrets behind some traditions and customs that engage with magic, especially "roots," which many describe as an abrupt illness or bad luck brought on by a curse. Connected to evil spirits, a root targets a person for the purpose of causing harm: "someone had put a root on that person" (p.45). Jerkins traces the origin of this tradition by researching the Gullah Geechee's powers of healing and cursing. For Gullah people, spirits are "as though they were flesh and blood" (p.45). However, African Americans differ in their outlook toward spirits, with some regarding the healers of the community as demonic and to be avoided. For many Blacks, the spiritual and natural worlds are intertwined. While Jerkins's own family does not believe in spirits in the Lowcountry, if a person has been inflicted with "a root," a witchcraft doctor who is an expert in that art will be brought in to undo the root. Jerkins emphasizes that her great-grandmother did not believe in "roots" due to religious considerations, and that her family regards this tradition as superstition. Other African Americans rely on rituals that sometimes intersect with religious practices or traditional superstitions in healing, such as using olive oil to keep evil spirits out of the house.

Jerkins learns about other practices connected to Black traditions, such as when someone dies in the house, all the windows are opened to get the evil spirits to leave the body of the dead: "The root doctor and the root worker are sometimes the same person in our culture of Gullah Geechee" (p.45). Another religious practice is hoodoo, which Jerkins recognizes: "In hoodoo, dirt, especially graveyard dirt, is used to ward off evil intentions and spirits" (p.55). Jerkins manages to discover many of her ancestors' traditions that have become part and parcel of Black lives. However, her uncle Sam “doesn't practice hoodoo and condemns it all as demonic" (p.56). Jerkins adopts her grandmother's practice of anointing olive oil to keep evil spirits away from the house. For Blacks, both water and hoodoo can elicit feelings of fear, loss, destruction and death.

Some African Americans claim psychic healing through the power of Black folklore. Such supernatural powers are thought to come from West Africa, and are intimately tied to soil and water. However, after African Americans were Christianized, their connection with land and water became negligible. As a result, many African American superstitions became combined with the Christian faith, and the Great Migration also influenced the economic, cultural, social and religious lives of Blacks. Continued White supremacy in the South did not give the Gullah Geechee the freedom to maintain their traditions or their estates. Marginalized and oppressed, Black communities lost a large part of Beaufort County and Hilton Head Island in South Carolina, "one of the most lucrative places in the South" (p.67) and Brown says, "it has been a devastating blow to our community" (p.75). It was the beginning of this displacement by Whites that eventually pushed millions of Blacks to leave the South in search of better life conditions. Some of the oldest ancestry of African Americans can be traced to the Gullah Geechee, and they are also a rich source of Black culture and history.

During Jerkins's journey to trace her roots, she was told many stories about White violence against Blacks, especially Blacks who were enslaved on White rice plantations. Jerkins recounts: "Tiffany told me a story of one woman who resisted Roswell King, a former manager of Butler Island Plantation, was whipped, then sent on a boat, where she was raped en route to Five Pound Island" (p. 41). The experience of Dr. Edda Fields-Black, an associate professor in the History Department at Carnegie Mellon University, illustrates the point: "Many of her relatives on her father's side, the Fields family, have been buried on this plantation, (p.42). Throughout Jerkins's time in Georgia, she comes across many stories about the Gullah Geechee, considered the earliest of ancestors for most African Americans, and their culture and history.

\section{The Creole and Louisiana Identity}

Jerkins discovers that her parental father's roots are Creole, from Louisiana, and that her Published by Sciedu Press 
Grandmother-grandmother's family were landowners. With this new information, Jerkins begins down the path that will lead her to her middle name - Régis - and its origin: "But the French, the couche-couche, the Regis name, the parish, and that intergenerational privilege were all the threads I needed to return to the original ball of yarn (p.83). Cleveland Sr., Jerkins's great-great-grandfather, lived on Davis Street, including French town to show her belonging to the Creole. Furthermore, five of the family's Louisiana Creoles migrated to Houston for better economic opportunities. The beginning of this African American displacement was caused by White oppression or sometimes, natural disasters, such as the Great Mississippi Flood of 1927 that forced two hundred thousand African Americans, including Black Creoles, to leave their homes and lands in search of safety and protection.

The roots of Jerkins's first generation are Creole, along with the culture of "Creole Crap." The Black Creole brought his heritage to North Carolina and New Jersey, and Jerkins realizes: "Not all Creoles are light-skinned" (p.84). This matches the change in perceptions of Creoles across different periods and cultures. In 1929, Creoles were associated with Whites while in 1992, the American Heritage Dictionary provided five definitions of Creole, with two definitions referencing mixed Black and enslaved Africans born in the Americas.

In Louisiana, if someone was not enslaved and had a Spanish or French parent, they would be given the social status of Creole. "Creole culture is by definition part of African American culture. Creole people are not a race-at least not in the way America defines race. They are neither white nor black" (p.87). Eventually, the term Creole evolved to include any mixed heritage and any native with American roots.

However, Creoles hold their own social, cultural and traditional practices, which sometimes differ from other Americans. While it is a distinct culture, it is also part of African diaspora and Black cultures. Louisiana Creoles were distinguished by their color and language, and were described as French-speaking Blacks, namely, Louisiana French Creole. Accordingly, Jerkins realized that "this trip was more than a reclamation of the Regises' past and my own. It was also a disentanglement of black ethnic identity as it twists and turns under the powers and laws of white supremacy" (p.93).

The Creole community of the past faded after the American Civil War and during the Jim Crow era. Among the limited number who remained, many sought better economic opportunities outside of Louisiana. And as Creoles, rather than Blacks, they were able to move on and fulfill their goals in life. "According to Professor Andrew Jolivétte, there were many Creoles who abandoned their culture the farther they moved away from Louisiana" (p.98). As for Jerkins's goal of finding her ancestral roots, she is able to determine that "the Regises were descended from Louisiana Creoles" (p.99).

Louisiana's special traditions are mingled with superstitions and religion, which are also part of Louisiana Creole customs. For example, Louisiana people believe in voodoo and its power, and some are considered practitioners of voodoo rites. While others regard such rites as demonic, as well as a source of fear and anxiety, the "veve" is associated with voodoo symbols and manifests as one of the spiritual forces recognized by faith. "Louisiana Voodoo is a syncretized religion that combines French Roman Catholicism and West African spirituality and religions via the transatlantic slave trade" (p.115).

\section{The Displacement of the Cherokee Nation}

White supremacy also forcibly removed hundreds of thousands of Native Americans from the Southeast to Oklahoma, known as Indian territory. During the Native American migration, more than a million enslaved Black people became part of the Trail of Tears, also forced to leave the South.

Jerkins's mother Sanbil and her sister Sharene both have connections with Native American ancestry, manifested in their brown skin and dark hair. Jerkins directs her efforts to identifying other relatives with an Indian association, in part due to their high cheekbones and reddish-brown skin. After much research, Jerkins realizes that part of her family is ethnic: Creole and Native American. However, discrimination against Blacks forced them to move from the South to establish their own community in the North, paving the way for a larger civil movement.

There are a group of Oklahomans described by the Cherokee nation as having high cheekbones and being Black. They were known as freedmen, however, not everyone with slick, dark hair has Cherokee ancestors. Eventually, the Blacks became disconnected from their native identity and heritage. Very early on, George Washington attempted to solve the "Indian problem" by providing the main native nations-Cherokee, Seminole, Greek, Choctaw and Chickasaw - with a good education and converting them to Christianity. However, Andrew Jackson later transferred many thousands of acres of land belonging to native nations to White farmers. In doing so, he forced thousands of Cherokee people to move west of the Mississippi River into Oklahoma on the forced march known as the Trail of Tears. Jerkins's family traced their roots to the Cherokee nation, while Seminoles continued to live in Georgia and 
Florida: “They took the money and ran. They raped the land and killed all the trees, killed the soil. You can't even plant down here. All the granite rock will kill a garden" (p. 151). The suffering of Blacks continued, and their relocation to the North or the West was not a magic solution.

Los Angeles was the last stop for Jerkins on her journey to trace her family history, where two of her uncles became successful in music production. California was a promised land for Blacks hoping to find better job opportunities and a breath of freedom. However, Los Angeles was not paradise found and in many ways, no different from any other city in America. It didn't take long for Blacks to realize that shifting their geography would not make a difference. The influx of African Americans to Los Angeles heightened anxiety among Whites. Therefore, Whites began to form gangs to protect their families because they saw Blacks as a source of danger. Such gangs spread during the 1940s in Huntington Park, Bel Air and Southgate, in particular. As a result, Blacks in Los Angeles were deprived access to good paying jobs in construction and other industries. In California in general, Blacks encountered violence, segregation, discrimination and persecution, sanctioned by the police and the courts. Black communities were neglected and had no chance of securing equal rights or, at least, the right to express themselves.

In the epilogue, Jerkins gives more attention to her journey and the goals that drove her to travel to different regions to trace her roots. She emphasizes that migration from one city to another did not end the problems for Blacks:

We migrate because we want something better. We migrate because we have no other choice. But no matter where we go, we're victims of segregation, redlining, and racial discrimination. We're separated from other family members, separated from our stories, separated from our belief systems, separated from our lineages and our very identity, because if we ever fully understood just how vast and interconnected we are - as most white people do - we would be even more formidable and less exploitable. (p.204)

At the end of Jerkins's journey, she realizes that "the promised land does not exist. Racism abides in all zip codes, on every migratory route" (p.206). The roots of Blacks are deep and endless. Ultimately, she understands that she cannot restrict Black history to specific groups; it is rich and far-reaching. In other words, Black history is a large and inseparable part of American history and heritage. "If we are the promised land, then that means that you-yes, you - exist on a plane larger than your eyes can see. Home is wherever we decide to settle, but our truest base is one another" (p.206). Jerkins manages to collect quite a bit of data about local Creoles, native African tribes and Native Americans, and she finds her own roots in each of these groups. Jerkins discovered that her mother's lineage can be traced back to the Gullah Geechee of Georgia, while her father's ancestry came from the Creole of Louisiana. "I entered into Louisiana as Morgan Jerkins. I returned to New York City as Morgan Simone Régis Jerkins. I am a black and Creole woman, a descendant of slaves, slave owners, and free people of color" (p.128). Jerkins finds information not only about the roots of her own family, but also about the greater ancestry of African Americans. Her data are supported by transcripts, photos, reports, records, interviews and investigations that lead the reader to the origins of Black heritage, to those who were a part of the Great Migration and to Jerkin's findings, all of which are a good addition to the history of African Americans and Native people in general.

\section{Conclusion}

Jerkins attempts to search for her roots because she has many questions about her family's identity, traditions, cultures and rituals that were not answered by her parents. Similarly, she received few answers about such traditions from the first generation of her family, who came from the South in search of better economic opportunities. Seeing how such traditions and customs were passed from one generation to another, Jerkins's most pressing questions were concerned with soul food, fear of water, rootwork, hoodoo and voodoo rites, and other traditions combining religious rituals and superstitious traditions.

Accordingly, Jerkins decided to research her family's roots following the routes of the Great Migration. She begins her journey in the Lowcountry of Georgia, searching for answers to her most puzzling questions. She wants to understand her past and her family lineage, as well as the associated traditions and rituals inherited by younger generations without any knowledge of their origins. Uncovering some key information leads Jerkins to part of her family's lineage connected with the Gullah Geechee. In Louisiana, she discovers the origins of the word "Creole," as well as a connection with her family. Eventually, Jerkins finds out that some of her relatives have deep roots among Native Americans.

Oklahoma was the second destination Blacks and Native Americans were forced to settle under White polices of marginalization, oppression and displacement, opening the door to steal Black and local lands, and implement policies of segregation. Jerkins found that some her relatives are connected to the Cherokee nation. 
The last stop was Los Angeles, which provided Jerkins with more data about her identity and roots. Los Angeles was a promised land in the eyes of many African Americans, but they quickly realized it was not the magic solution to their problems, failing to provide a safe refuge.

Jerkins illustrated that the history and culture of African Americans is rich and far-reaching, covering a large part of American history and heritage. Jerkins not only uncovered her identity and her lineage but through her journey of self-exploration, provided sufficient new data about her family, African Americans and native peoples in general.

\section{References}

Ashcroft, B., Griffiths, G., \& Tiffin, H. (2007). Post-Colonial Studies: The Key Concepts (2nd ed.). Routledge.

Baharian, S., Barakatt, M., Gignoux, C. R., Shringarpure, S., William, J. E., Blot, J., ... Gravel, S. (2016, May 27). The Great Migration and African-American Genomics Diversity. PLOS Genetics. https://doi.org/10.1371/journal.pgen.1006059

Black, D. A., Sanders, S. G., Tylor, E. J., \& Tylor, L. J. (2015). The Impact of the Great Migration on Mortality of African-Americans: Evidence from the Deep South. American Economic Review, 195(2), 477-503. https://doi.org/10.1257/aer.20120642

Bonner, P. (2004). The Great Migration and the Greatest Trek: Some Reflections. Journal of Southern African Studies, 30(1), 87-114. https://doi.org/10.1080/0305707042000223951

Calderon, A., Fouka, V., \& Tabellini, M. (2021, April). Racial Diversity, Electoral Preferences, and the Supply of Policy: The Great Migration and Civil Rights. Institute of Labor Economics, IZA DP No. 14312. https://doi.org/10.2139/ssrn.3841893

Collins, W. J., \& Wanmaker, M. H. (2015). The Great Migration in Black and White: New Evidence on the Selection and Sorting of Southern Migrants. The Journal of Economic History, 75(4), 947-992. https://doi.org/10.1017/S0022050715001527

Donofrio, T. A., \& Samek, A. A. (2019). Women's Studies in Communication. Routledge.

Dribe, J. M., Hacker, D., \& Scalone, F. (2018). Becoming American: Intermarriage during the Great Migration to the United States. Journal of Interdisciplinary History, 49(2), 189-218. https://doi.org/10.1162/jinh_a_01266

Elder, R. K. (2016, October 31). The Great Migration. The New York Times.

Gardner, J. (2016). Immigration and Wages: New Evidence from the African American Great Migration. IZA Journal of Migration, 5(22). https://doi.org/10.1186/s40176-016-0070-2

Gardner, J. (2020). Intergenerational altruism in the migration decision calculus: Evidence from the African American Great Migration. Journal of Population Economics, 33, 115-154. https://doi.org/10.1007/s00148-019-00738-5

Jerkins, M. (2020). Wandering in Strange Lands. Harper Collins Publishers.

Kirby, J. (2018). Morgan Jerkins Should Write Us More Often. Feminist Collections: a Quarterly of Women's Studies Resources, 41(1/2), 9-10.

Mah, A. (2019). A layover stop in African American great migration: Identity, ruination, and memory. Ethnic and Racial Studies, 42(13), 2326-2332. https://doi.org/10.1080/01419870.2019.1605090

Mingo, A. M. (2021). Black and Blue: Black Women, 'Law Order', and the Church's Silence on Police Violence. Religions, 12(886). https://doi.org/10.3390/rel12100886

Reny, T. T., \& Newman, B. J. (2018). Protecting the Right to Discriminate: The Second Great Migration and Racial Threat in the American West. American Political Science Review, 12(4), 1104-1110. https://doi.org/10.1017/S0003055418000448

Tibbs, D. F. (2021). From Tiktok to Racial Violence: Anti-blackness in the Gendered Sphere. Thomas Law Review.

Trent, A. J., Leibrand, C., Massey, C., \& Tolnay, S. (2017). Demography. Population Association of America. USA.

\section{Copyrights}

Copyright for this article is retained by the author(s), with first publication rights granted to the journal.

This is an open-access article distributed under the terms and conditions of the Creative Commons Attribution license (http://creativecommons.org/licenses/by/4.0/). 